\begin{tabular}{c} 
Volume and Issues Obtainable at Center for Sustainability Research and Consultancy \\
Responsible Education, Learning and Teaching in Emerging Economies \\
ISSN: 2708-4310 (E): 2708-4183 \\
Volume 1: No. 2, December 2019 \\
CSRᄃ \\
Journal homepage: www.publishing.globalcsrc.org/relate \\
\hline
\end{tabular}

\title{
Level of Performance of Students in Tree Crop Seedlings Production Skills in Colleges of Agriculture in North-Eastern Nigeria
}

\author{
${ }^{1}$ Adamu Usman \\ ${ }^{1}$ Department Of Agricultural Science Education, School Of Vocational Education, Federal College Of \\ Education (Technical), Potiskum, Yobe State, Nigeria: usmanadamu347@ gmail.com
}

\begin{tabular}{l} 
ARTICLE DETAILS \\
\hline History \\
Revised format: November 2019 \\
Available Online: December 2019
\end{tabular}

\section{Keywords}

Performance, Skills, Tree Crop

Seedlings Production, Tree

Crops

\section{JEL Classification: \\ Q16, Q19}

\begin{abstract}
The study examined the level of performance of students in tree crop seedlings production skills in Colleges of Agriculture in North-Eastern Nigeria. Five objectives and five research questions guided the study. Single-subject A/B research design was used. The population of the study was 924 students from four Colleges of Agriculture in the study area. The sample of the study was 272 respondents drawn using stratified proportionate random sampling technique from the population. A performance work sample test made up of 100 items was used to determine the level of skill performance of students in Colleges of Agriculture in North-Eastern Nigeria. The instrument was validated by five experts drawn from Abubakar Tafawa Balewa University Bauchi, Federal University Dutse, Jigawa State, College of Agariculture Bauchi and Federal College of Horticulture Dadin Kowa, Gombe State. Reliability was established using test-retest method and Spearman rank order correlation co-efficient which yielded a reliabilty coefficient value of 0.80 . The instrument was administered by the researcher with the help of four trained research assistants. Data collected was analyzed using mean and standard deviation to answer the research questions. The findings of the study revealed that National Diploma (ND) II crop production students have exhibited high skill performance in pre-sowing operations, moderate skill performance in planting operations, high skill performance in nursery management, marketing and transplanting operations. It was recommended that teachers in Colleges of Agriculture should ensure regular practicals, demonstrations and supervision of (ND) II crop production students while conducting practical classes in tree crop seedlings production.
\end{abstract}

\section{OPEN ACCESS}

(C) 2019 The authors, under a Creative Commons Attribution-

NonCommercial 4.0

Corresponding author's email address: usmanadamu347@gmail.com

Recommended citation: Usman, A., (2019). Level of Performance of Students in Tree Crop Seedlings Production Skills in Colleges of Agriculture in North-Eastern Nigeria. Responsible Education, Learning and Teaching in Emerging Economies, 1(2),47-56

DOI: $10.26710 /$ relate.v1i2.1123

\section{Introduction}

The level of students' performance in agriculture can be determine by vocational skills in tree crop 
seedlings production (Salihu, 2013). Vocational agricultural education is concerned with the development of skills, knowledge and attitude in the field of agriculture to enable the recipients take up a career in it. It is responsible in preparing individuals in various agricultural occupations such as those concerned with growing crops, rearing animals, providing ornamental horticulture, managing farm business and farm resources (Ezeagu \& Ezema, 2004). However, skill performance remain the main goal of vocational education and this help to satisfy the personal work needs of both the individual and the society. Therfore, to exhibit skill performance in vocational agricultural programmes such as tree crop seedlings production in Colleges of Agriculture level, opportunities must be provided for students to practice the skills they are taught in an environment relevant to the practical skills learnt (Oladosu \& Sanusi, 2004).

In tree crop seedlings production, skills are manual processes acquired through repetitive performance of operation. Therefore, a person is said to have demonstrated a skill, when he/she can finish a given practical work at a given time with minimal error (Neck, 2000). Ashmore (2006) observed that skill performance can be done through participation in carrying out practical work and that practical work provides feedback about student learning experience which is referred to as evaluation. The author further stated that skill performance is cumbersome, tideous and time consuming.

Tree Crop Seedlings Production (TCSP) is farming enterprise that deals with careful manipulation of environment and soil fertility to raise seedlings in the nursery before transplanting to the field or permanent site (Oladosu \& Sanusi, 2004). In the nursery, the young seedlings are tendered from sowing to develop in such a way as to be able to endure the hard field conditions (Salihu, 2013). Whether local or introduced species, Food and Agricultural Organization [FAO] (2009) reported that nursery seedlings are found to have better survival than seeds sown directly in the field or through natural regeneration. Amusa and Dumbiri (2010) described a nursery in tree crop production and management as an area where seedlings of plants are carefully nurtured to be sold or transplanted into the permanent field at certain stage of development.

Tree crop is a general term used to refer to woody perennials that are cultivated on a large scale and under intensive management and chiefly as export crops (Salihu, 2013). He added that they are generally referred to as tree crop because they remain on the farmland for several years just like trees giving periodic yields. Purseglove (2012), ascertained that the ecology of the different tree crops in Nigeria is closely related to the situation of the rain forest belt along the coast and the savannah zones located to the north. He further added that the common features of the general ecology are: altitude and winds, rainfall, temperature, humidity, irradiation and photoperiod, soils and distribution of the tree crops. Opeke (2005), adduced that the Nigerian tree crop producing areas have two distinct zones. These include: the southern most strip along the coast, up to 60 kilometres in width, has red ferrallitic soils developed on loose sandy sediments. While, the northern part of the area consists of ferruginous tropical soils, developed from crystalline acid rocks. Therefore, the ferrallitic soils of low fertility predominate in the tree crop belt. However, Purseglove (2012) opined that the important tree crop producing areas in Nigeria are situated partly on ferrallitic soils and partly on ferruginous tropical soils respectively.

The tree crop sub-sector is very important in Africa and in particular Nigerian agriculture for its significant contributions to farmer's income, generation of employment, environmental conservation and generation of foreign exchange. It also has multiplier effect on the economy, provision of raw-materials for agro-allied industries, reduction of green house gasses, improvement of soil fertility, rural development, contribution to government revenue, provision of food and fodder and nutrient recycling (Salihu, 2013). It serves as major source of income and gainful employment to about $40 \%$ of people in tree crop producing states (Oladosu \& Sanusi, $2004 \&$ Babatola, 2007). This has also made the production of tree crop seedlings a lucrative and profitable farm enterprise (Salihu, 2013). Hence, Sonwa, Weise and Janssens (2007) stated that from available evidence, nursery business has improved the livelihood of many rural community members. In the nursery business, the cultural practices in tree crop seedlings production is in the following sequence: pre- sowing operations, planting operations, nursery management 
operations, marketing operations and transplanting operations. Therefore these cultural practices were in line with the specific objectives of the study as contained in tree crop production course in National Diploma (ND) II level in Colleges of Agriculture in Nigeria National Board for Technical Education [NBTE] (2007).

The establishment of Colleges of Agriculture in Nigeria, aims at imparting knowledge and training to learners in agricultural production and the acquisition of practical skills, attitudes, understanding and knowledge related to occupations in various sector of agriculture (NBTE, 2007). While giving an account of various efforts made by government to boost Colleges of Agriculture in Nigeria toward the production of tree crop seedlings, there are many plant species in Nigeria which are potentially useful but which still remain unknown to the international market and are not expoited (Opeke, 2005). He further stressed that few of these tree crops are Margic plants, Thoumatococus danielli L (Lam), White star apple, African pear, Monkey kola, Shea butter, Aidan tree and other promising plant species such as Garcinnia kola (bitter, orogbo and akilu). Therefore, it is in line with this assertion that this study was set to determine the level of performance of students in tree crop seedlings production skills in Colleges of Agriculture in North-Eastern Nigeria.

\section{Methodology}

Single-subject A/B research design was used. The population of the study was 924 students from four Colleges of Agriculture in the study area. The sample of the study was 272 respondents drawn using stratified proportionate random sampling technique from the population. A performance work sample test made up of 100 items was used to determine the level of skill performance of students in Colleges of Agriculture in North-Eastern Nigeria. The instrument was validated by five experts drawn from Abubakar Tafawa Balewa University Bauchi, Federal University Dutse, Jigawa State, College of Agariculture Bauchi and Federal College of Horticulture Dadin Kowa, Gombe State. Reliability was established using test-retest method and Spearman rank order correlation co-efficient which yielded a reliabilty coefficient value of 0.80 . The instrument was administered by the researcher with the help of four trained research assistants. Data collected was analyzed using mean and standard deviation to answer the research questions.

\section{Results and Discussions}

The results and the analysis of data for this study were presented based on the research questions raised to guide the study.

\subsection{Level of Performance in Pre-Sowing Operation Skills by Students of Colleges of Agriculture in Tree Crop Seedlings Production}

The results in Table 3, shows that students of Colleges of Agriculture in all the 20 pre-sowing operation skills were performed at three different levels. The construct mean scores ranging from 3.51 to 3.89 indicated high skill performance, construct mean scores ranging from 3.41 to 3.44 indicated moderate skill performance and a construct mean score of 3.27 indicated low skill performance. Therefore, the grand mean score of 20 pre-sowing operation skills was 3.65. This indicated the cluster skill performance of students in Colleges of Agriculture was high in pre-sowing operation skills. The above results is in line with the findings obtained by Hussain, Iqbal and Akhtar (2010) which revealed that Colleges of Agriculture students have exhibited most of the pre-sowing operation skills in tree crop production such as selection of simple farm tools, clearing of nursery site, clear felling, bruising of thrashes and debris, ability to mix top soil with manure and filling of containers with fertile top-soils respectively.

\subsection{Level of Performance in Planting Operation Skills by Students of Colleges of Agriculture in Tree Crop Seedlings Production}

The results in Table 4, shows that students of Colleges of Agriculture in all the 20 planting operation skills were performed at three different levels. The construct mean scores ranging from 3.50 to 3.93 indicated high skill performance, construct mean scores ranging from 3.38 to 3.49 indicated moderate 
skill performance and construct mean scores ranging from 3.12 to 3.23 indicated low skill performance. Therefore, the grand mean score of 20 planting operation skills was 3.45. This indicated the cluster skill performance of students in Colleges of Agriculture was moderate in planting operation skills. In the same vein, Ahmed (2015) observed that Colleges of Agriculture students in Yobe State have exhibited the skill performance in planting operations at moderate level in tree crop production. This was also consisted with the findings of Yakubu (2014) who conducted a study in tree crop seedlings production and reported that Colleges of Agriculture students have demonstrated moderate skill performance in good placement of seeds into planting holes and ability to provide shade to planted cuttings respectively.

\subsection{Level of Performance in Nursery Management Skills by Students of Colleges of Agriculture in Tree Crop Seedlings Production}

The results in Table 5, shows that students of Colleges of Agriculture in all the 20 nursery management skills were performed at three different levels. The construct mean scores ranging from 3.56 to 3.96 indicated high skill performance, construct mean score of 3.30 indicated moderate skill performance and construct mean score of 3.13 indicated low skill performance. Therefore, the grand mean score of 20 nursery management skills was 3.70. This indicated the cluster skill performance of students in Colleges of Agriculture was high in nursery management operations. This results is in conformity with the findings otained by Salihu (2013) where he reported that crop production students have practicalized moderate skill performance in identification of the correct fertilizer to be applied when tree crops shows the deficiency of macro-nutrients.

\subsection{Level of Performance in Marketing Operation Skills by Students of Colleges of Agriculture in Tree Crop Seedlings Production}

The results in Table 6, shows that students of Colleges of Agriculture in all the 20 marketing operation skills were performed at three different levels. The construct mean scores ranging from 3.56 to 3.95 indicated high skill performance, construct mean scores ranging from 3.34 to 3.46 indicated moderate skill performance and construct mean scores ranging from 3.24 to 3.29 indicated low skill performance. Therefore, the grand mean score of 20 marketing operation skills was 3.60. This indicated the cluster skill performance of students in Colleges of Agriculture was high in marketing operation skills. The above results is in line with Amusa and Dumbiri (2010) who observed that retirees have exhibited the skill performance in marketing operations at high level in Ekiti State of South-Western, Nigeria. Okafor, Okeme \& Oketoobo (2010) have also reported that senior secondary school leavers have equally practicalized the marketing operation skills at high performance level in Oil palm seedlings prodution.

\subsection{Level of Performance in Transplanting Operation Skills by Students of Colleges of Agriculture in Tree Crop Seedlings Production}

The results in Table 7, shows that students of Colleges of Agriculture in all the 20 transplanting operation skills were performed at three different levels. The construct mean scores ranging from 3.50 to 4.06 indicated high skill performance, construct mean scores ranging from 3.38 to 3.45 indicated moderate skill performance and construct mean scores ranging from 3.11 to 3.15 indicated low skill performance. Therefore, the grand mean score of 20 marketing operation skills was 3.50. This indicated the cluster skill performance of students in Colleges of Agriculture was high in transplanting operation skills. These findings agreed with the results obtained by Okafor, Okeme and Oketoobo (2010) where they reported that Secondary school leavers have demonstrated moderate skill performance in uprooting seedlings with small ball of earth, ability to perform good watering of seedlings, ability to drain excess water from seedlings base and determination of unrecovered seedlings after transplanting oprations. 
Table 1: Population Distribution of Students in Colleges of Agriculture of 2018/2019 Academic Session

\begin{tabular}{|lll|}
\hline S/No & Name of Institutions & Number of Students \\
\hline 1. & Bauchi State College of Agriculture, Bauchi & 222 \\
2. & College of Agriculture Gujba, Yobe State & 19 \\
3. & College of Agriculture Jalingo, Taraba State & 635 \\
4. & Federal College of Horticulture Dadin-Kowa, Gombe State & 48 \\
\hline & Total & $\mathbf{9 2 4}$ \\
\hline
\end{tabular}

Source: Field survey (2018 \& 2019).

Table 2: Colleges of Agriculture, Population Distribution, Percentage and Sample of Students in 2018/2019 Academic Session

\begin{tabular}{|l|l|l|l|l|}
\hline S/No & Colleges of Agriculture & Population & Percentage & Sample \\
\hline 1. & Bauchi State College of Agriculture, Bauchi & 222 & 24.00 & 65 \\
\hline 2. & College of Agriculture Gujba, Yobe State & 19 & 2.00 & 5 \\
\hline 3. & College of Agriculture Jalingo, Taraba State & 635 & 69.00 & 188 \\
\hline 4. & $\begin{array}{l}\text { Federal College of Horticulture Dadin-Kowa, } \\
\text { Gombe State }\end{array}$ & 48 & 5.00 & 14 \\
\hline & Total & $\mathbf{9 2 4}$ & $\mathbf{1 0 0}$ & $\mathbf{2 7 2}$ \\
\hline
\end{tabular}

Source: Field survey (2018 \& 2019).

Table 3: Mean and Standard Deviation of Responses of Performance in Pre-sowing Operation Skills by Students of Colleges of Agriculture in Tree Crop Seedlings Production.

\begin{tabular}{|c|c|c|c|c|}
\hline $\mathbf{S} / \mathbf{N}$. & Pre-sowing Operation Skills & $\overline{\mathbf{X}}$ & SD & Remarks \\
\hline 1. & $\begin{array}{l}\text { Correct selection of simple farm tools for clearing of } \\
\text { nursery site }\end{array}$ & 3.89 & 1.14 & $\mathrm{HP}$ \\
\hline 2. & Good clear felling & 3.75 & 1.11 & $\mathrm{HP}$ \\
\hline 3. & Good brushing of thrashes & 3.81 & 1.09 & $\mathrm{HP}$ \\
\hline 4. & Correct tree seedlings thinning & 3.44 & 1.19 & MP \\
\hline 5. & Proper packing of thrashes and debris & 3.56 & 1.12 & $\mathrm{HP}$ \\
\hline 6. & Abilty to clear a site for nursery & 3.59 & 1.23 & HP \\
\hline 7. & Ability to remove thrashes and debris & 3.62 & 1.34 & $\mathrm{HP}$ \\
\hline 8. & Ability to break down soil clods & 3.61 & 1.34 & $\mathrm{HP}$ \\
\hline 9. & Ability to carry out soil sterilization & 3.27 & 1.04 & LP \\
\hline 10. & Ability to level the nursery site & 3.63 & 1.24 & $\mathrm{HP}$ \\
\hline 11. & Ability to mix top soil and manure & 3.81 & 1.15 & $\mathrm{HP}$ \\
\hline 12. & $\begin{array}{l}\text { Ability to make drainage holes at the base of } \\
\text { portable containers }\end{array}$ & 3.51 & 1.31 & $\mathrm{HP}$ \\
\hline 13. & Ability to fill the containers with fertile top soils & 3.75 & 1.15 & $\mathrm{HP}$ \\
\hline 14. & $\begin{array}{l}\text { Ability to determine the upper portion of containers } \\
\text { for water retention }\end{array}$ & 3.66 & 1.25 & $\mathrm{HP}$ \\
\hline 15. & $\begin{array}{l}\text { Ability to arrangement ready made portable } \\
\text { containers under shade }\end{array}$ & 3.69 & 0.98 & $\mathrm{HP}$ \\
\hline 16. & Good use of watering can & 3.69 & 1.08 & $\mathrm{HP}$ \\
\hline 17. & Complete watering of nursery & 3.86 & 1.14 & $\mathrm{HP}$ \\
\hline
\end{tabular}




\begin{tabular}{|l|l|l|l|l|}
\hline S/N. & Pre-sowing Operation Skills & $\overline{\mathbf{X}}$ & SD & Remarks \\
\hline 18. & Ability to avoid excessive watering & 3.76 & 1.10 & HP \\
\hline 19. & Ability to determine optimal watering & 3.41 & 1.37 & MP \\
\hline 20 & Ability to wash watering can after used & 3.80 & 1.13 & HP \\
\hline & Grand Mean & $\mathbf{3 . 6 5}$ & $\mathbf{1 . 1 8}$ & HP \\
\hline
\end{tabular}

Source: Field survey (2018 \& 2019).

Key: $\mathrm{X}=$ Mean, SD = Standard Deviation, $\mathrm{HP}=$ High Performance, MP = Moderate Performance and LP $=$ Low Performance.

Table 4: Mean and Standard Deviation of Responses of Performance in Planting Operation Skills by Students of Colleges of Agriculture in Tree Crop Seedlings Production.

\begin{tabular}{|c|c|c|c|c|}
\hline S/N. & Planting Operation Skills & $\overline{\mathbf{X}}$ & SD & Remarks \\
\hline 1. & Ability to carry out floatation of seeds & 3.50 & 1.12 & $\mathrm{HP}$ \\
\hline 2. & Ability to perform scarification & 3.60 & 1.22 & $\mathrm{HP}$ \\
\hline 3. & $\begin{array}{l}\text { Ability to soak seeds in } 2,3,4 \text {, triphenyl- } \\
\text { tetrazolium }\end{array}$ & 3.93 & 1.31 & $\mathrm{HP}$ \\
\hline 4. & $\begin{array}{l}\text { Ability to determine the colour of cotyledons } \\
\text { (seedleaves) }\end{array}$ & 3.53 & 1.14 & $\mathrm{HP}$ \\
\hline 5. & Ability to identify a viable seed & 3.56 & 1.16 & $\mathrm{HP}$ \\
\hline 6. & Good selection of viable seeds & 3.61 & 1.24 & $\mathrm{HP}$ \\
\hline 7. & Good digging of planting holes and drills & 3.43 & 1.27 & MP \\
\hline 8. & Correct planting holes and drills & 3.52 & 1.15 & HP \\
\hline 9. & $\begin{array}{l}\text { Good placement of seeds into planting holes and } \\
\text { drills }\end{array}$ & 3.42 & 1.10 & MP \\
\hline 10. & $\begin{array}{l}\text { Abilty to sow seeds in nursery beds filled with } \\
\text { sterilised soil }\end{array}$ & 3.12 & 1.16 & LP \\
\hline 11. & $\begin{array}{l}\text { Good placement of seeds into filled portable } \\
\text { containers }\end{array}$ & 3.48 & 1.14 & MP \\
\hline 12. & $\begin{array}{l}\text { Ability to cover the sown seeds with fertile } \\
\text { topsoils }\end{array}$ & 3.42 & 1.31 & MP \\
\hline 13. & $\begin{array}{l}\text { Ability to placed cuttings into ready made } \\
\text { containers }\end{array}$ & 3.23 & 1.14 & LP \\
\hline 14. & $\begin{array}{l}\text { Ability to cover the lower part of cuttings in } \\
\text { slanting direction }\end{array}$ & 3.15 & 1.31 & LP \\
\hline 15. & Ability to provide shade to planted cuttings & 3.38 & 1.18 & MP \\
\hline 16. & Ability to obtain a uniform sample of seedlot & 3.52 & 1.15 & HP \\
\hline 17. & $\begin{array}{l}\text { Good moistening of planted seeds as often as } \\
\text { possible }\end{array}$ & 3.93 & 1.32 & HP \\
\hline 18. & Ability to keep sown seeds at high temperature & 3.44 & 1.01 & MP \\
\hline 19. & Ability to count a representative of sample seeds & 3.48 & 1.19 & MP \\
\hline \multirow[t]{2}{*}{20} & $\begin{array}{l}\text { Ability to calculate the percentage of germinated } \\
\text { seeds }\end{array}$ & 3.49 & 1.18 & MP \\
\hline & Grand Mean & 3.45 & 1.14 & MP \\
\hline
\end{tabular}

Source: Field survey (2018 \& 2019).

Key: $\mathrm{X}=$ Mean, SD = Standard Deviation, HP = High Performance, MP = Moderate Performance and LP $=$ Low Performance. 
Table 5: Mean and Standard Deviation of Responses of Performance in Nursery Management Skills by Students of Colleges of Agriculture in Tree Crop Seedlings Production.

\begin{tabular}{|l|l|l|l|l|}
\hline S/N. & Nursery Management Skills & $\mathbf{X}$ & $\mathbf{S D}$ & Remarks \\
\hline 1. & Ability to clean the nursery properly & 3.77 & 1.14 & HP \\
\hline 2. & Ability to slash weeds using hoe or cutlass & 3.87 & 1.01 & HP \\
\hline 3. & Ability to select the right herbicide & 3.79 & 1.16 & HP \\
\hline 4. & Proper cutting of bush undergrowth & 3.66 & 1.18 & HP \\
\hline 5. & Clearing of all unwanted debris & 3.83 & 1.14 & HP \\
\hline 6. & Ability to determine pest or disease infection & 3.62 & 1.25 & HP \\
\hline 7. & $\begin{array}{l}\text { Ability to detect type of pest or disease causing } \\
\text { organism }\end{array}$ & 3.66 & 1.23 & HP \\
\hline 8. & Ability to select good pesticide & 3.56 & 1.14 & HP \\
\hline 9. & $\begin{array}{l}\text { Abilty to mix chemical and water in knapsack } \\
\text { sprayer }\end{array}$ & 3.83 & 1.23 & HP \\
\hline 10. & $\begin{array}{l}\text { Ability to shake mixtures and proper use of } \\
\text { knapsack sprayer }\end{array}$ & 3.74 & 1.13 & HP \\
\hline 11. & Abilty to determine fertilizer needs of the plant & 3.78 & 1.25 & HP \\
\hline 12. & $\begin{array}{l}\text { Ability to identify the correct type of fertilizer to } \\
\text { be applied }\end{array}$ & 3.30 & 1.01 & MP \\
\hline 13. & Ability to select mixed fertilizer & 3.13 & 1.03 & LP \\
\hline 14. & Ability to apply fertilizer by ring method & 3.92 & 1.21 & HP \\
\hline 15. & Ability to apply fertilizer using knapsack sprayer & 3.89 & 1.30 & HP \\
\hline 16. & $\begin{array}{l}\text { Correct type of herbicide, pesticide and fertilizer } \\
\text { used }\end{array}$ & 3.61 & 1.22 & HP \\
\hline 17. & Effectiveness of chemicals used & 3.96 & 1.33 & HP \\
\hline 18. & Correct measurement of chemicals and water used & 3.57 & 1.18 & HP \\
\hline 19. & Removal of weeds, pest and diseases & 3.87 & 1.14 & HP \\
\hline 20. & Time taken to complete the operations & 3.86 & 1.12 & $\mathbf{0 . 9 9}$ \\
\hline & Grand Mean & & H.70 & \\
\hline
\end{tabular}

Source: Field survey (2018 \& 2019).

Key: $\mathrm{X}=$ Mean, $\mathrm{SD}=$ Standard Deviation, HP $=$ High Performance, MP $=$ Moderate Performance and LP $=$ Low Performance.

Table 6: Mean and Standard Deviation of Responses of Performance in Marketing Operation Skills by Students of Colleges of Agriculture in Tree Crop Seedlings Production.

\begin{tabular}{|l|l|l|l|l|}
\hline S/N. & Marketing Operation Skills & $\mathbf{X}$ & SD & Remarks \\
\hline 1. & Ability to pack seedlings into containers & 3.29 & 1.14 & LP \\
\hline 2. & Ability to brand seedlings in case of substitutes & 3.93 & 1.20 & HP \\
\hline 3. & Ability to fix price on tree crop seedlings & 3.56 & 1.10 & HP \\
\hline 4. & Ability to name seedlings & 3.29 & 1.14 & LP \\
\hline 5. & Ability to advertise seedlings & 3.38 & 1.13 & MP \\
\hline 6. & Ability to provide seedlings directly to buyers & 3.61 & 1.22 & HP \\
\hline 7. & $\begin{array}{l}\text { Ability to sale good seedlings in larger quantities to } \\
\text { retailers }\end{array}$ & 3.95 & 1.07 & HP \\
\hline 8. & $\begin{array}{l}\text { Ability to sale matured seedlings directly to } \\
\text { consumers/users }\end{array}$ & 1.56 & HP \\
\hline
\end{tabular}




\begin{tabular}{|l|l|l|l|l|}
\hline S/N. & Marketing Operation Skills & $\mathbf{X}$ & SD & Remarks \\
\hline 9. & Ability to bagain on seedlings price & 3.83 & 1.23 & HP \\
\hline 10. & Ability to use chain of distribution of seedlings & 3.70 & 1.21 & HP \\
\hline 11. & Ability to reduce bulkiness & 3.46 & 1.23 & MP \\
\hline 12. & Ability to reduce mortality & 3.34 & 1.25 & MP \\
\hline 13. & Ability to maintain seasonal seedlings & 3.24 & 1.24 & LP \\
\hline 14. & Ability to control disease attack on seedlings & 3.69 & 1.14 & HP \\
\hline 15. & Ability to control pest infestation on seedlings & 3.88 & 1.06 & HP \\
\hline 16. & Seeling of good seedlings & 3.79 & 1.39 & HP \\
\hline 17. & Selling of matured seedlings & 3.94 & 1.22 & HP \\
\hline 18. & Good seedlings substitutes & 3.67 & 1.26 & HP \\
\hline 19. & Time taken to complete the task (bargaining) & 3.66 & 1.17 & HP \\
\hline 20. & Use of proper marketing channel & 3.81 & 1.15 & HP \\
\hline & & & & \\
\hline & Grand Mean & $\mathbf{3 . 6 0}$ & $\mathbf{1 . 1 8}$ & HP \\
& & & & \\
\hline
\end{tabular}

Source: Field survey (2018 \& 2019).

$\bar{K}$ ey: $\mathrm{X}=$ Mean, SD = Standard Deviation, HP = High Performance, MP $=$ Moderate Performance and LP $=$ Low Performance.

Table 7: Mean and Standard Deviation of Responses of Performance in Transplanting Operation Skills by Students of Colleges of Agriculture in Tree Crop Seedlings Production.

\begin{tabular}{|l|l|l|l|l|}
\hline S/N. & Transplanting Operation Skills & $\mathbf{X}$ & SD & Remarks \\
\hline 1. & Proper uprooting of seedlings with ball of earth & 3.38 & 1.23 & MP \\
\hline 2. & $\begin{array}{l}\text { Ability to uproot seedlings in the morning on } \\
\text { transplanting day }\end{array}$ & 3.65 & 1.39 & HP \\
\hline 3. & Good treatment of uprooted seedlings with clay slurry & 3.54 & 1.24 & HP \\
\hline 4. & Good transportation of uprooted seedlings & 3.67 & 1.20 & HP \\
\hline 5. & $\begin{array}{l}\text { Ability to allow the uprooted seedlings to rest prior to } \\
\text { transplanting }\end{array}$ & 3.11 & 1.04 & LP \\
\hline 6. & Ability to dig the correct size of transplanting hole & 3.50 & 1.11 & HP \\
\hline 7. & $\begin{array}{l}\text { Ability to half-filled the transplanting hole with top } \\
\text { soil and compost }\end{array}$ & 3.61 & 1.32 & HP \\
\hline 8. & $\begin{array}{l}\text { Ability to arrange the seedling roots properly and } \\
\text { consolidating soil to it }\end{array}$ & 3.78 & 1.04 & HP \\
\hline 9. & $\begin{array}{l}\text { Ability to completely eliminate air pockets from the } \\
\text { seedling root zone }\end{array}$ & 3.62 & 1.71 & HP \\
\hline 10. & $\begin{array}{l}\text { Ability to plant the uprooted seedlings as early as } \\
\text { possible }\end{array}$ & 3.51 & 1.02 & HP \\
\hline 11. & Ability to perform good watering & 3.41 & 1.08 & MP \\
\hline 12. & Ability to drain excess water from seedling base & 3.45 & 1.12 & MP \\
\hline 13. & $\begin{array}{l}\text { Ability to pull the top leaf without dislocating the } \\
\text { seedling }\end{array}$ & 3.70 & 1.18 & HP \\
\hline 14. & Ability to apply compost to seedlings properly & 3.60 & 1.19 & HP \\
\hline 15. & Ability to apply pesticide to control pest & 3.53 & 1.12 & HP \\
\hline 16. & Good watering on recovered seedlings & 3.15 & 1.15 & LP \\
\hline 17. & Evidence of new leaves development in seedlings & 1.13 & HP \\
\hline 18. & Percentage recovery of seedlings after transplanting & 3.65 & 1.16 & HP \\
\hline
\end{tabular}




\begin{tabular}{|l|l|l|l|l|}
\hline S/N. & Transplanting Operation Skills & $\mathbf{X}$ & SD & Remarks \\
\hline 19. & $\begin{array}{l}\text { Percentage of unrecovered seedlings after two weeks } \\
\text { of transplanting }\end{array}$ & 3.43 & 1.27 & MP \\
\hline 20. & Time taken to complete transplanting & 4.06 & 0.94 & HP \\
\hline & Grand Mean & $\mathbf{3 . 5 0}$ & $\mathbf{1 . 1 2}$ & HP \\
\hline
\end{tabular}

Source: Field survey (2018 \& 2019).

$\overline{\text { Key }}: \mathrm{X}=$ Mean, SD $=$ Standard Deviation, HP $=$ High Performance, MP $=$ Moderate Performance and LP $=$ Low Performance.

\section{Conclusion}

Based on the results obtained in this study, (ND) II crop production students have demonstrated high skill performance in pre-sowing operations, nursery management, marketing and transplanting operations respectively. There are other areas where (ND) II crop production students exhibited moderate and low skill performance in planting operations. It was concluded that (ND) II crop production students have practicalized high skill performance in pre-sowing, nursery management, marketing and transplanting operations respectively. While they exhibited moderate skill performance in planting operations in (TCSP).

\section{Recommendations}

The following recommendations were made based on the findings of the study:

- Teachers in Colleges of Agriculture should engage (ND) II crop production students in conducting practicals in pre-sowing operation skills like ability to carry out soil sterilization because they exibited low skill performance.

- Lecturers in Colleges of Agriculture should ensure regular supervision of (ND) II crop production students while they are conducting practical classes in planting operation skills like the ability to sow seeds in nursery beds filled with sterilised soils and ability to cover the lower part of cuttings in slanting direction.

- Teachers in Colleges of Agriculture should expose (ND) II crop production trip in appropriate nurseries in order to practicalize some of the nursery skills like ability to select mixed fertilizer for tree crop seedlings production.

- Teachers in Colleges of Agriculture should give more emphasis in marketing operation skills in order to train crop production students through demonstrations in ability to pack seedlings into containers, ability to name seedlings and ability to maintain seasonal seedlings because they have demonstrated low skill performance.

- Teachers in Colleges of Agriculture should give more attention and priority during explanations and demostrations in areas of transplanting operation skills like ability to allow the uprooted seedlings to rest prior to transplanting and good watering of recovered seedlings due to delicate nature of transplanting operations.

\section{References}

Ahmed, S. D. (2015). Application of tree crop production in colleges of agriculture. Unpublished manuscript.

Amusa, T. A. \& Dumbiri, D. N. (2010). Entrepreneurial skills required by retirees for tree crop seedlings production in Ekiti State, Nigeria. Nigerian Vocational Association Journal 15 (1), 368-378.

Ashmore, C. (2006, March, 10). The consortium for entrepreneurship education assessment rubric for national standards of practice for entrepreneurship education. Retrieved on July 10 2012, from: http://www.entre-ed.org/testimony.htm.

Babatola, J. O. (2007 September). The Nigeria experience. Text of paper presented by Federal Government of Nigeria at the meeting of Sustainable Cocoa Economy on 2nd African Cocoa 
Submit, Accra, Ghana.

Ezeagu, S. E. \& Ezema, P. N. (2004). Introduction to vocational education. Enugu: Ozybel Publishers. p. 32.

Food and Agricultural Organization (2009, August, 2). Techniques of nursery operations in arid zones (Chap. 1). Retrieved on July 10, 2010; from: http://www.fao.org/docrep/ pp. 3 - 4.

Hussain, M. A., Iqbal, M. Z. \& Akhtar, M. S. (2010). Technology based learning environment and student's achievement in agriculture in Pakistan. Journal of World Academic of Science, Engineering and Technology 62 (2), 178-180.

National Board for Technical Education (2007). Entrepreneurship education for polytechnics and similar institutions. Teachers Guide. Kaduna: NBTE Press Publishers. Pp. 2 - 3.

Neck, A. N. (2000). Professionalism in teaching agriculture: What and How. The Agricultural Education Magazines 54 (2), 30-35.

Okafor, N. B., Okeme, I. \& Oketoobo, E. A. (2010). Entrepreneurial skills required by secondary school graduates in palms production in Anambra State, Nigeria. Nigerian Vocational Association Journal 15 (1), 172-183.

Oladosu, I. O. \& Sanusi, W. A. (2004). Communication effectiveness between Cocoa Research Institute of Nigeria (CRIN) and cocoa farmers in cocoa producing areas in Oyo state. Journal of Rural Research and Information 1 (2), $77-\quad 86$.

Opeke, L. K. (2005). Tropical commodity tree crops. Ibadan: Spectrum Books Limited. Pp. 1 - 5.

Purseglove, J. W. (2012). Underexploited tropical plants with promising economic value. Washington, D.C.: National Academy of Sciences. Pp. $30-31$.

Salihu, M. N. (2013). Tree crop production for schools and colleges. Unpublished manuscript. Pp. 1 - 6.

Sonwa, D., Weise, S. \& Janssens, M. (2007). New synergies in the promotion of cocoa based agroforestry systems in the humid forest zone of West and Central Africa. Retrieved on July 10, 2010, from: http://www.etfrn.org/etffrn/index.html

Yakubu, Y. (2014). Tree crop seedlings production: a focus on expoited species. Poster session presented at Colleges of Agriculture Scholars Conference. Damaturu. 